\author{
KAROLINA ZAPOLSKA \\ ORCID: 0000-0003-2859-6996 \\ Uniwersytet w Białymstoku \\ k.zapolska@uwb.edu.pl
}

\title{
Wpływ samorządowych organów ochrony środowiska na działalność gospodarczą przedsiębiorcy
}

\begin{abstract}
Abstrakt: Celem artykułu jest analiza wpływu samorządowych organów ochrony środowiska w ograniczaniu działalności gospodarczej w Polsce. W tym zakresie autorka przeanalizowała zadania i kompetencje samorządowych organów ochrony środowiska na każdym etapie działalności gospodarczej. Autorka przedstawia rozwiązania normatywne w tym zakresie. Artykuł przedstawia także podejście do ograniczania wolności gospodarczej ze względu na ochronę środowiska w doktrynie prawa, kończy się zaś syntetycznymi wnioskami. Badanie zarysowanych problemów opierało się głównie na metodzie dogmatyczno-prawnej.
\end{abstract}

Słowa kluczowe: ochrona środowiska, działalność gospodarcza, przedsiębiorca, organ ochrony środowiska.

\section{Uwagi wprowadzające}

Truizmem jest stwierdzenie, że skuteczne rozwiązywanie problemów z zakresu ochrony środowiska wymaga podejmowania kompleksowych działań. Właściwa ochrona środowiska wymaga współpracy władz publicznych i jednostek. Ochrona środowiska jest przy tym konstytucyjnym zadaniem państwa, które w tym zakresie ,decyduje o ochronie środowiska oraz o wykorzystaniu jego zasobów"1. Państwo swoje zadania w tym zakresie realizuje oczywiście przez wła-

1 M. Walas, Organy ochrony środowiska w Polsce, PPOŚ 2009, nr 1, s. 41; por. M. Górski, Ochrona środowiska jako zadanie administracji publicznej, Łódź 1992, s. 33 n. 
ściwe organy administracji publicznej, które występują w roli organów ochrony środowiska.

Podstawowym celem artykułu jest przedstawienie samorządowych organów ochrony środowiska, a także ustalenie ich potencjalnego wpływu na poszczególne etapy działalności gospodarczej. Taka konstrukcja problemu badawczego wymaga na wstępie ustalenia, kto $\mathrm{w}$ polskim porządku prawnym jest samorządowym organem ochrony środowiska, następnie zaś zbadania, jaki jest wpływ samorządowych organów ochrony środowiska na podejmowanie, wykonywanie i zakończenie działalności gospodarczej. Tym samym autorka będzie analizować, czy ze względu na ochronę środowiska dany samorządowy organ ochrony środowiska ma jakieś kompetencje lub zadania wobec przedsiębiorcy.

Punktem wyjścia jest niewątpliwie ustawa - Prawo ochrony środowiska ${ }^{2}$ będąca jednym $\mathrm{z}$ najważniejszych aktów prawnych regulujących zagadnienie ochrony środowiska. P.o.ś. do kwestii związanej z organami ochrony środowiska odwołuje się pośrednio w art. 3 pkt 14 p.o.ś., zawierającym definicję organu administracji, zgodnie z którą jest nim:

a) minister, centralne organy administracji rządowej, wojewoda, działające $\mathrm{w}$ ich lub we własnym imieniu inne terenowe organy administracji rządowej, organy jednostek samorządu terytorialnego;

b) podmiot, gdy jest on powołany z mocy prawa lub na podstawie porozumień do wykonywania zadań publicznych dotyczących środowiska i jego ochrony.

Bezpośrednie odniesienie do problematyki organów ochrony środowiska $\mathrm{w}$ art. 3 pkt 15 p.o.ś., zgodnie z którym organem ochrony środowiska jest organ administracji powołany do wykonywania zadań publicznych z zakresu ochrony środowiska, stosownie do ich właściwości określonej w tytule VII w dziale I. Jego konkretyzacja następuje w art. 376 p.o.ś., w którym enumeratywnie zostają wymienione organy ochrony środowiska. Należy do nich wójt, burmistrz lub prezydent miasta, starosta, sejmik województwa, marszałek województwa, wojewoda, minister właściwy do spraw środowiska, Generalny Dyrektor Ochrony Środowiska, a także regionalny dyrektor ochrony środowiska.

Dostrzegalny jest przy tym znaczący udział organów związanych z samorządem terytorialnym. Ochrona środowiska jest tym samym jednym $z$ wielu obowiązków organów JST. W związku z tym w roli organu ochrony środowiska pojawia się wójt, burmistrz lub prezydent miasta, starosta, sejmik województwa oraz marszałek województwa. Na potrzeby niniejszego artykułu będę je określać jako samorządowe organy ochrony środowiska.

${ }^{2}$ Ustawa z dnia 27 kwietnia 2001 roku Prawo ochrony środowiska (Dz.U. z 2018 r. poz. 799 ze zm.), dalej: p.o.ś. 


\section{Samorządowe organy ochrony środowiska a legalizacja działalności gospodarczej}

Legalizacją działalności gospodarczej jest realizacja przez podmiot zainteresowany wykonywaniem działalności gospodarczej wszystkich warunków wymaganych przez przepisy prawa, aby dana działalność była zgodna z prawem. Co do zasady legalizacja wiąże się ze zobowiązaniem przedsiębiorcy do złożenia wniosku o wpis we właściwym rejestrze - Centralnej Ewidencji i Informacji o Działalności Gospodarczej (CEIDG) lub Krajowym Rejestrze Sądowym (KRS). Ponadto, w ramach legalizacji, podmiot powinien uzyskać wpis między innymi w Krajowym Rejestrze Urzędowym Podmiotów Gospodarki Narodowej (REGON), Krajowej Ewidencji Podatników, Centralnym Rejestrze Płatników Składek oraz Centralnym Rejestrze Ubezpieczonych ${ }^{3}$.

Warto w tym miejscu podkreślić, że organy ochrony środowiska, w tym samorządowe organy ochrony środowiska, nie mają kompetencji w ramach legalizacji opartej na podstawowych zgłoszeniach, a więc klasycznie rozumianej legalizacji. W zakresie legalizacji działalności gospodarczej pośredniego wpływu samorządowych można dopatrzyć się natomiast w prowadzeniu przez nie niektórych rejestrów i ewidencji związanych z ochroną środowiska. W tym miejscu można wskazać na wprowadzone w marcu 2018 roku rejestry podmiotów wprowadzających produkty, produkty w opakowaniach i gospodarujących odpadami (BDO), które są prowadzone przez marszałków województw ${ }^{4}$.

\section{Samorządowe organy ochrony środowiska a reglamentacja działalności gospodarczej}

W polskim porządku prawnym wyróżnia się trzy formy reglamentacji działalności gospodarczej — koncesje, działalność regulowaną oraz zezwolenia. Działalnością regulowaną jest działalność gospodarcza, której wykonywanie wymaga od przedsiębiorcy spełnienia dodatkowych, wskazanych przepisami prawa, obowiązków. Zgodnie z art. 43 ustawy z dnia 6 marca 2018 roku — Prawo przedsiębiorców ${ }^{5}$, dany rodzaj działalności jest działalnością regulowaną, jeżeli odrębne przepisy tak stanowią. Aby podjąć działalność regulowaną, niezbęd-

3 C. Kosikowski i M. Etel podkreślają, że dopiero wypełnienie tych obowiązków legalizuje działalność gospodarczą; C. Kosikowski, M. Etel, Nowe prawo działalności gospodarczej, Białystok 2014, s. 141.

4 Zostały one wprowadzone na podstawie art. 49 ustawy z dnia 14 grudnia 2012 roku o odpadach (Dz.U. z 2019 r. poz. 701 z późn. zm.), dalej: u.o.

5 Dz.U. z 2018 r. poz. 646 ze zm., dalej: u.p.p. 
ne jest spełnienie przez przedsiębiorcę dodatkowych obowiązków określonych przepisami odrębnych ustaw, złożenie przez przedsiębiorcę wniosku o dokonanie wpisu w odpowiednim rejestrze działalności regulowanej wraz z oświadczeniem o spełnieniu warunków szczególnych wymaganych do wykonywania danej działalności oraz wpisanie przedsiębiorcy do odpowiedniego rejestru przez właściwy organ prowadzący rejestr działalności regulowanej ${ }^{6}$.

Samorządowe organy ochrony środowiska prowadzą rejestry w zakresie regulowanej działalności gospodarczej. Jako przykład można wskazać marszałka województwa, który na podstawie art. 18 ustawy z dnia 13 października 1995 roku — Prawo łowieckie ${ }^{7}$ prowadzi rejestr działalności regulowanej w zakresie działalności polegającej na świadczeniu usług turystycznych obejmujących polowania wykonywane na terytorium Rzeczypospolitej Polskiej i polowania za granicą. Ponadto dostrzegalna jest w tym zakresie rola wójta (burmistrza, prezydenta miasta), który na podstawie ustawy z dnia 13 września 1996 roku o utrzymaniu czystości i porządku w gminach ${ }^{8}$, prowadzi rejestr działalności regulowanej w zakresie odbierania odpadów komunalnych od właścicieli nieruchomości (art. 9b ust. 1 i 2 u.c.p.g.) $)^{9}$. Dodatkowo wójt (burmistrz, prezydent miasta), wykreśla z rejestru działalności regulowanej w zakresie odbierania odpadów komunalnych od właścicieli nieruchomości w przypadku, gdy ${ }^{10}$ :

- wydano prawomocne orzeczenie zakazujące przedsiębiorcy wykonywania działalności gospodarczej objętej wpisem;

— stwierdzono trwałe zaprzestanie wykonywania przez przedsiębiorcę działalności gospodarczej na terenie gminy objętej wpisem;

— stwierdzono, że przedsiębiorca nie spełnia wymagań określonych dla podmiotu odbierającego odpady komunalne od właścicieli nieruchomości;

- stwierdzono, że przedsiębiorca po raz drugi przekazuje zmieszane odpady komunalne lub odpady zielone do instalacji innych niż regionalne instalacje do przetwarzania odpadów komunalnych;

— przedsiębiorca, który nie działa na podstawie umowy, o której mowa w art. $6 f$ ust. 1 u.c.p.g. i nie świadczy usługi odbierania odpadów komunalnych w trybie zamówienia $\mathrm{z}$ wolnej ręki ${ }^{11}$, w kolejnym roku kalendarzowym nie osiągnął poziomów

${ }^{6}$ Art. 43 ust. 2 u.p.p.; C. Kosikowski, M. Etel, op. cit., s. 166. Szerzej M. Etel, Regulowana działalność gospodarcza a zasada wolności gospodarczej, „Państwo i Prawo” 2007, nr 2, s. 41-52; M. Szydło, Reglamentacja podejmowania działalności gospodarczej w nowej ustawie o swobodzie działalności gospodarczej, PUG 2004, nr 12, s. 2; K. Kohutek, Zasady podejmowania działalności regulowanej, PPH 2005, nr 6, s. 35.

7 Dz.U. z 2019 r. poz. 125 z późn. zm., dalej: u.p.ł.

${ }^{8}$ Dz.U. z 2018 r. poz. 1454 ze zm., dalej: u.c.p.g.

9 Zob. szerzej A. Kosieradzka-Federczyk, Funkcje administracyjne w gospodarce odpadami na przyktadzie gminy, [w:] Prawne aspekty gospodarowania zasobami środowiska. Korzystanie z zasobów środowiska, red. B. Rakoczy, M. Szalewska, K. Karpus, Toruń 2014, s. 264.

10 Art. 9j u.c.p.g.

11 Art. 6 f ust. 2 u.c.p.g. 
recyklingu, przygotowania do ponownego użycia i odzysku innymi metodami oraz ograniczenia masy odpadów komunalnych ulegających biodegradacji przekazywanych do składowania ${ }^{12}$.

Poza obowiązkiem prowadzenia rejestru samorządowe organy ochrony środowiska w zakresie działalności regulowanej mają również wiele dodatkowych obowiązków, w tym między innymi obowiązek dokonywania wpisów, aktualizacji i zmiany treści wpisów na wniosek przedsiębiorcy, dokonywania wykreśleń $\mathrm{z}$ rejestru, prostowania z urzędu wpisów zawierających oczywiste błędy lub niezgodności ze stanem faktycznym, zapewnienia dostępu do danych i informacji zawartych w rejestrze, wydawania zaświadczeń o wpisie czy też wydania decyzji o zakazie wykonywania przez przedsiębiorcę działalności gospodarczej ${ }^{13}$.

Jak już zostało wskazane, w polskim porządku prawnym inną formą działalności reglamentowanej są zezwolenia. Uzyskania zezwolenia wymaga wykonywanie działalności gospodarczej w zakresie określonym w odrębnych przepisach. W związku z tym o kwestiach związanych z organami zezwalającymi oraz warunkami wykonywania działalności objętej zezwoleniem, w tym z zasadami oraz trybem udzielania, odmową udzielenia, zmianą, zawieszeniem, cofnięciem albo ograniczeniem zakresu zezwolenia, przesądzają przepisy ustaw odrębnych ${ }^{14}$. Zgodnie z art. 43 u.p.p. organ zezwalający udziela zezwolenia na wykonywanie działalności gospodarczej przedsiębiorcy spełniającemu wymagane prawem warunki uzyskania zezwolenia. Tym samym zezwolenie jest decyzją administracyjną o charakterze związanym. W zezwoleniu organ stwierdza, że nie występują przeszkody, które uniemożliwiłyby podjęcie i wykonywanie działalności gospodarczej przez podmiot ubiegający się o zezwolenie ${ }^{15}$.

Kompetencje w zakresie udzielania zezwoleń mają również samorządowe organy ochrony środowiska, czego przykładem jest między innymi marszałek województwa, który:

a) na podstawie art. 41 u.o. udziela zezwolenia na prowadzenie działalności gospodarczej w zakresie zbierania odpadów i ich przetwarzania (łącznie ze starostą oraz regionalnym dyrektorem ochrony środowiska):

— dla przedsięwzięć mogących zawsze znacząco oddziaływać na środowisko w rozumieniu u.d.u.o.ś.;

12 Określonych w przepisach wydanych na podstawie art. $3 \mathrm{~b}$ ust. $2 \mathrm{i}$ art. $3 \mathrm{c}$ ust. 2 u.c.p.g.

13 Por. M. Etel, [w:] Prawo pocztowe. Komentarz, red. M. Chołodecki, A. Piszcz, T. Skoczny, Warszawa 2018, s. 116.

14 Art. 42 ust. 2 u.p.p.

15 Szerzej na ten temat C. Kosikowski, Zezwolenia na działalność gospodarcza w prawie polskim, Warszawa 1997; P. Korzeniowski, Prawa i obowiązki przedsiębiorców w ochronie środowiska. Zarys encyklopedyczny, Warszawa 2010, s. 173; por. C. Kosikowski, M. Etel, op. cit., s. 161-162; C. Kosikowski, Zezwolenie na działalność gospodarcza, [w:] Administracyjne prawo gospodarcze, red. L. Kieres, Wrocław 2009, s. 298; K. Strzyczkowski, Prawo gospodarcze publiczne, Warszawa 2013, s. 240. 
— dla odpadów innych niż niebezpieczne, poddawanych odzyskowi w procesie odzysku polegającym na wypełnianiu terenów niekorzystnie przekształconych, jeżeli ilość umieszczanych w wyrobisku lub zapadlisku odpadów jest nie mniejsza niż $10 \mathrm{Mg}$ na dobę lub całkowita pojemność wyrobiska lub zapadliska jest nie mniejsza niż $25000 \mathrm{Mg}$;

— dla regionalnych instalacji do przetwarzania odpadów komunalnych i dla instalacji określonych w wojewódzkim planie gospodarki odpadami jako regionalne instalacje do przetwarzania odpadów komunalnych.

b) na wniosek zarządzającego składowiskiem wydaje decyzję zatwierdzającą instrukcję prowadzenia składowiska odpadów, która jest niezbędnym elementem, aby zarządzający składowiskiem odpadów mógł rozpocząć działalność polegającą na prowadzeniu składowiska odpadów ${ }^{16}$.

$\mathrm{W}$ analizowanym zakresie dostrzegalna jest również rola starosty, który udziela zezwolenia na prowadzenie działalności w zakresie zbierania odpadów i ich przetwarzania łącznie z marszałkiem województwa oraz RDOŚ ${ }^{17}$. Co więcej, również wójt (burmistrz, prezydent miasta), który udziela zezwolenia na opróżnianie zbiorników bezodpływowych i transport nieczystości ciekłych ${ }^{18}$, ochronę przed bezdomnymi zwierzętami ${ }^{19}$, prowadzenie schronisk dla bezdomnych zwierząt, a także grzebowisk i spalarni zwłok zwierzęcych i ich części ${ }^{20}$, prowadzenie zbiorowego zaopatrzenia $w$ wodę ${ }^{21}$, zbiorowe odprowadzanie ścieków ${ }^{22}$. Ponadto, przed podjęciem decyzji w sprawie wydania zezwolenia, wójt, burmistrz lub prezydent miasta może $\mathrm{e}^{23}$ :

1. wezwać przedsiębiorcę do uzupełnienia, w wyznaczonym terminie, jednak nie krótszym niż 14 dni, brakującej dokumentacji poświadczającej, że przedsiębiorca spełnia warunki określone przepisami prawa, wymagane do wykonywania działalności objętej zezwoleniem;

2. dokonać kontrolnego sprawdzenia faktów podanych we wniosku o udzielenie zezwolenia w celu stwierdzenia, czy przedsiębiorca spełnia warunki wykonywania działalności objętej zezwoleniem;

3. odmówić wydania zezwolenia, zmienić lub cofnąć zezwolenie w drodze decyzji.

Warto podkreślić, że samorządowe organy ochrony środowiska nie mają kompetencji w przypadku koncesji, a więc najsurowszej formy reglamentacji działalności gospodarczej.

16 Art. 128 ust. 1 i 2 u.o.

17 Art. 44 ust. 3 pkt 2 u.o.

18 Art. 7 ust. 1 pkt $2 \mathrm{w}$ związku z art. 7 ust. 6 u.c.p.g

19 Art. 7 ust. 1 pkt $3 \mathrm{w}$ związku z art. 7 ust. 6 u.c.p.g.

${ }^{20}$ Art. 7 ust. 1 pkt $4 \mathrm{w}$ związku z art. 7 ust. 6 u.c.p.g.

21 Art. 16 ust. 1 ustawy z dnia 7 czerwca 2001 roku o zbiorowym zaopatrzeniu w wodę i zbiorowym odprowadzaniu ścieków (Dz.U. z 2018 r. poz. 1152); dalej: u.z.z.w.

22 Art. 16 ust. 1 u.z.z.w.

23 Art. 8 a ust. 1 u.z.z.w. 


\section{Organy ochrony środowiska a kontrola działalności gospodarczej}

Samorządowe organy ochrony środowiska odgrywają istotną rolę przede wszystkim w kontrolowaniu przedsiębiorców w kontekście ochrony środowiska ${ }^{24}$. W tym zakresie kompetencje ma zarówno wójt, burmistrz lub prezydent miasta, marszałek województwa, starosta, jak i sejmik województwa ${ }^{25}$.

Na podstawie art. 60 ust. 1 u.p.p. wójt, burmistrz lub prezydent miasta jest zobowiązany do niezwłocznego zawiadomienia właściwego organu administracji publicznej w razie powzięcia wiadomości o wykonywaniu działalności gospodarczej niezgodnie z przepisami ustawy, a także w razie stwierdzenia zagrożenia życia lub zdrowia, niebezpieczeństwa powstania szkód majątkowych w znacznych rozmiarach lub naruszenia środowiska w wyniku wykonywania tej działalności ${ }^{26}$. Warto podkreślić, że zawiadomione w ten sposób organy administracji publicznej są zobowiązane do niezwłocznego powiadamiania wójta, burmistrza lub prezydenta miasta o podjętych czynnościach. Analizowany artykuł nie wskazuje jednak, który z tych organów powinien zostać w tym przypadku zawiadomiony przez wskazane samorządowe organy ochrony środowiska ${ }^{27}$.

Co istotne, ustawa - Prawo przedsiębiorców przewiduje również, że w sytuacji braku możliwości zawiadomienia właściwych organów administracji publicznej, wójt, burmistrz lub prezydent miasta może nakazać, w drodze decyzji, wstrzymanie wykonywania działalności gospodarczej na czas niezbędny, nie dłuższy niż trzy dni ${ }^{28}$. Decyzji tej nadaje się rygor natychmiastowej wykonalności, a sama decyzja ma charakter czasowy ${ }^{29}$. Tego typu uprawnienie powstaje tylko w przypadku, gdy nie ma możliwości zawiadomienia właściwego organu administracji publicznej. Wciąż aktualny jest pogląd C. Kosikowskiego, że taka

24 J. Ciechanowicz-McLean, Prawo i polityka ochrony środowiska, Warszawa 2009, s. 151.

25 A. Barczak, E. Kowalewska, Zadania samorzadu terytorialnego w ochronie środowiska. Aspekty materialne i finansowe, Warszawa 2015, s. 174; por. T. Suski, J. Kierzkowska, Rola organów samorzadu terytorialnego w zakresie prawnej ochrony przyrody w Polsce, [w:] Prawne aspekty gospodarowania zasobami środowiska. Korzystanie z zasobów środowiska, red. B. Rakoczy, M. Szalewska, K. Karpus, Toruń 2014, s. 201-210.

26 Szerzej na ten temat E.K. Czech, M. Kropiewnicka, Międzynarodowa wspótpraca polskiego samorzadu terytorialnego szczebla powiatowego $w$ zakresie ochrony środowiska realizowanej w zgodzie ze zrównoważonym rozwojem, „Białostockie Studia Prawnicze” 2012; por. E.K. Czech, Kompetencje samorządu terytorialnego w zakresie ochrony środowiska a możliwość prywatyzacji przedsięwzięć publicznych, [w:] Integracja Polski z Unia Europejska w dziedzinie ochrony środowiska - problemy, korzyści, zagrożenia, red. M. Burchard-Dziubińska, Łódź 2000, s. 283-284.

27 C. Kosikowski, Ustawa o swobodzie działalności gospodarczej. Komentarz, Warszawa 2012, s. 419-420.

28 Art. 60 ust. 3 u.p.p.

29 Art. 60 ust. 34 u.p.p. 
sytuacja wystąpi w dwóch przypadkach — po pierwsze, gdy wójt, burmistrz lub prezydent miasta nie wie, kogo powinien poinformować lub po drugie, gdy „próby zawiadomienia są odpierane przez organy, które uważają się za niewłaściwe w sprawie albo też zawiadomienie odbywa się w czasie wolnym od pracy (na przykład tak zwane długie weekendy, ferie świąteczne)"30.

Niewątpliwie art. 60 u.p.p. umożliwia wskazanym samorządowym organom ochrony środowiska zareagowanie na informacje dotyczące wykonywania działalności gospodarczej w sposób zagrażający między innymi środowisku ${ }^{31}$.

Kompetencje kontrolne wójta, burmistrza lub prezydenta miasta są również zauważalne na podstawie art. 379 ust. 1 p.o.ś, zgodnie z którym sprawują oni kontrolę przestrzegania i stosowania przepisów o ochronie środowiska w zakresie objętym właściwością tych organów. W tym miejscu warto wskazać na uprawnienie wójta, burmistrza lub prezydenta miasta do:

1. nakazania, w drodze decyzji, osobie fizycznej, której działanie negatywnie oddziałuje na środowisko wykonania, w określonym czasie, czynności zmierzających do ograniczenia ich negatywnego oddziaływania na środowisko lub przywrócenia środowiska do stanu właściwego (art. 363 ust. 1 p.o.ś);

2. wstrzymania, w drodze decyzji, użytkowania instalacji lub urządzenia, jeżeli osoba fizyczna nie dostosowała się do wymagań decyzji wydanej na podstawie art. 363 ust. 1 p.o.s. ${ }^{32}$;

3. wstrzymania, w drodze decyzji, użytkowania instalacji lub urządzenia, z których emisja nie wymaga pozwolenia, a prowadzonej przez osobę fizyczną w ramach zwykłego korzystania ze środowiska, jeżeli osoba fizyczna nie dostosowała się do warunków wskazanych w decyzji określającej wymagania dotyczące eksploatacji (art. 368 ust.1 p.o.ś);

4. wystąpienia do wojewódzkiego inspektora ochrony środowiska o podjęcie odpowiednich działań będących w jego kompetencji, jeżeli w wyniku kontroli wójt, burmistrz lub prezydent miasta stwierdził naruszenie przez kontrolowany podmiot przepisów o ochronie środowiska lub występuje uzasadnione podejrzenie, że takie naruszenie mogło nastąpić (art. 379 ust. 4 p.o.s. $)^{33}$;

5. upoważnienia do wykonywania funkcji kontrolnych pracowników podległych im urzędów lub funkcjonariuszy straży gminnych (art. 379 ust. 2 p.o.ś.);

6. występowania w charakterze oskarżyciela publicznego w sprawach o wykroczenia przeciw przepisom o ochronie środowiska (art. 379 ust. 3 p.o.ś.).

Ważne uprawnienia związane z kontrolą i nadzorem wynikającymi z ochrony środowiska ma również starosta. $\mathrm{W}$ ich zakresie starosta może przede wszystkim wystąpić do wojewódzkiego inspektora ochrony środowiska ${ }^{34}$ o podjęcie odpo-

30 C. Kosikowski, Ustawa o swobodzie działalności gospodarczej..., s. 419.

31 Ibidem, s. 420.

32 Art. 368 ust. 2 p.o.ś.

33 A. Barczak, E. Kowalewska, op. cit., s. 182.

34 Dalej: WIOŚ. 
wiednich działań będących w jego kompetencji, jeżeli w wyniku kontroli wójt, burmistrz lub prezydent miasta stwierdził naruszenie przez kontrolowany podmiot przepisów o ochronie środowiska lub występuje uzasadnione podejrzenie, że takie naruszenie mogło nastąpić ${ }^{35}$. Starosta może również prowadzić okresowe badania jakości gleby i ziemi ${ }^{36}$ oraz obserwację terenów zagrożonych ruchami masowymi ziemi oraz terenów, na których występują te ruchy, a także rejestr zawierający informacje o tych terenach ${ }^{37}$. Dodatkowo starosta wydaje decyzję:

1. o dopuszczalnym poziomie hałasu w przypadku stwierdzenia, że poza zakładem, w wyniku jego działalności, przekroczone są dopuszczalne poziomy hałasu (art. 115a ust. 1 p.o.ś.);

2. w sprawie nałożenia obowiązku prowadzenia w określonym czasie pomiarów emisji, jeżeli z przeprowadzonej kontroli wynika, że nastąpiło przekroczenie standardów emisyjnych (art. 150 ust. 1 p.o.ś.);

3. jeżeli stwierdzono, że podmiot korzystający ze środowiska negaty nie oddziałuje na środowisko - w której może nałożyć obowiązek ograniczenia oddziaływania na środowisko lub przywrócenia środowiska do stanu właściwego, określając równocześnie zakres ograniczenia lub stan, do jakiego ma zostać przywrócone środowisko, a także czynności zmierzające do osiągnięcia tych celów (art. 362 ust. 1-3 p.o.ś.).

Starosta może również upoważnić do wykonywania funkcji kontrolnych pracowników podległych mu urzędów lub funkcjonariuszy straży gminnych ${ }^{38}$. Podobne kompetencje ma również marszałek województwa oraz wójt, burmistrz lub prezydent miasta.

Pośrednie kompetencje w zakresie kontroli działalności gospodarczej ma również sejmik województwa, który ma możliwość wskazania sposobu realizacji i późniejszej kontroli wprowadzonych przez niego w drodze uchwały, ograniczeń lub zakazów w zakresie eksploatacji instalacji, w których następuje spalanie paliw ${ }^{39}$. W tym zakresie sejmik województwa można wskazać na dwie przesłanki wprowadzenia ograniczeń lub zakazów w celu zapobieżenia negatywnemu oddziaływaniu na środowisko lub w celu zapobieżenia negatywnemu oddziaływaniu na zdrowie ludzi ${ }^{40}$.

Również marszałek województwa ma uprawnienia do kontroli działalności gospodarczej w zakresie ochrony środowiska ${ }^{41}$. Zgodnie z p.o.ś., marszałek wo-

35 Art. 379 ust. 4 p.o.ś

36 Art. 101 d ust. 3 p.o.ś.

37 Art. 110a ust. 1 p.o.ś.

38 Art. 379 ust. 2 p.o.ś.

39 Zgodnie z art. 96 p.o.ś.

40 Z. Bukowski, Możliwości prawne wprowadzenia zakazu spalania określonych paliw stałych na terenie gminy, „Studia z Zakresu Prawa, Administracji i Zarządzania” 1, 2012, s. 50; por. J. Ciechanowicz-McLean, Z. Bukowski, B. Rakoczy, Prawo ochrony środowiska. Komentarz, Warszawa 2008, s. 220-221.

41 A. Barczak A., E. Kowalewska, op. cit., s. 174. 
jewództwa może wystąpić do WIOŚ o podjęcie odpowiednich działań będących w jego kompetencji, jeżeli w wyniku kontroli wójta, burmistrza lub prezydenta miasta stwierdzono naruszenie przez kontrolowany podmiot przepisów o ochronie środowiska lub występuje uzasadnione podejrzenie, że takie naruszenie mogło nastąpić (art. 379 ust. 4 p.o.ś.). Ponadto może wystąpić w charakterze oskarżyciela publicznego $\mathrm{w}$ sprawach o wykroczenia przeciw przepisom o ochronie środowiska (art. 379 ust. 3 p.o.ś.). Co więcej, marszałek województwa sprawuje nadzór i kontrolę w zakładach górniczych eksploatujących na podstawie udzielonych koncesji kopaliny ze złóż, a także nad wykonywaniem robót geologicznych w zakresie zgodności z zatwierdzonymi projektami. Marszałek województwa sprawuje również kontrolę nad podmiotami korzystającymi ze środowiska w zakresie wywiązywania się z obowiązków odnośnie do opłat za emisję gazów lub pyłów do powietrza, pobór wody, odprowadzanie ścieków do wód lub do ziemi, składowanie odpadów, to jest naliczanie i wnoszenie opłat ${ }^{42}$.

\section{Samorządowe organy ochrony środowiska a zawieszenie wykonywania działalności gospodarczej}

Zawieszenie wykonywania działalności gospodarczej umożliwia czasowe zaprzestanie wykonywania działalności gospodarczej, a jednocześnie pozwala na jej dalsze prowadzenie po wznowieniu ${ }^{43}$. Zgodnie z art. 25 ust. 2 u.p.p. w okresie zawieszenia wykonywania działalności gospodarczej przedsiębiorca ma obowiązek realizować wszelkie obowiązki określone przepisami prawa, w tym między innymi związane z ochroną środowiska (na przykład do ponoszenia opłat za korzystanie ze środowiska na rachunek właściwego urzędu marszałkowskiego) ${ }^{44}$.

Warto również podkreślić, że przedsiębiorca w okresie zawieszenia wykonywania działalności gospodarczej może zostać skontrolowany. Tym samym przed-

42 Art. 277 w związku z art. 379 ust. 1 p.o.ś.

43 C. Kosikowski, Ustawa o swobodzie działalności gospodarczej..., s. 117; por. A. Powałowski, Ocena regulacji prawnej zawieszenia wykonywania działalności gospodarczej, GSP 2010, nr 2, s. 339; M.A. Waligórski, Prawo przedsiębiorcy do zawieszania $i$ wznawiania wykonywania działalności gospodarczej, PUG 2009, nr 8; A. Piszcz, Zawieszenie $i$ wznowienie wykonywania działalności gospodarczej, PUG 2009, nr 10, s. 27-32; por. K. Roszewska, Wpływ zawieszenia działalności gospodarczej na ubezpieczenia emerytalne i rentowe, „Z Zagadnień Zabezpieczenia Społecznego” s. 39-60.

${ }^{44}$ K. Romas, Opłaty środowiskowe, gdy działalność została zawieszona, „Gazeta Podatkowa” 10.01.2013, http://www.gofin.pl/17,2,306,113384,oplaty-srodowiskowe-gdy-dzialalnosc-zostala-zawieszona.html (dostęp: 18.09.2019). 
siębiorca może podlegać w tym okresie kontroli właściwego samorządowego organu ochrony środowiska.

\section{Samorządowe organy ochrony środowiska a zakończenie działalności gospodarczej}

W kontekście zakończenia działalności gospodarczej ${ }^{45}$ niewątpliwie dostrzegalny jest wpływ samorządowych organów ochrony środowiska, między innymi w zakresie wykreślenia przedsiębiorcy z prowadzonych przez nie rejestrów czy też z uzyskaniem od przedsiębiorcy informacji na temat realizacji dotychczasowych obowiązków związanych z ochroną środowiska.

Co istotne, wiele organów ochrony środowiska ma możliwość wydania decyzji wstrzymującej działalność gospodarczą. W tym zakresie najwięcej uprawnień ma przede wszystkim WIOŚ; można jednak dostrzec wpływ samorządowych organów ochrony środowiska. Przykładowo, w razie naruszenia warunków decyzji określającej wymagania dotyczące eksploatacji instalacji, z której emisja nie wymaga pozwolenia, prowadzonej przez osobę fizyczną $w$ ramach zwykłego korzystania ze środowiska, wójt, burmistrz lub prezydent miasta może, w drodze decyzji, wstrzymać użytkowanie instalacji; wójt, burmistrz lub prezydent miasta może również, w drodze decyzji, wstrzymać użytkowanie instalacji lub urządzenia, jeżeli osoba fizyczna nie dostosowała się do wymagań decyzji, o której mowa w art. 363 p.o.s. ${ }^{46}$

Ponadto w przypadku stwierdzenia naruszeń warunków wymaganych do prowadzenia działalności gospodarczej właściwy marszałek województwa wzywa przedsiębiorcę do usunięcia naruszeń w wyznaczonym terminie; w przypadku nieusunięcia naruszeń marszałek województwa wydaje decyzję o zakazie wykonywania działalności gospodarczej przez okres trzech lat ${ }^{47}$. Dodatkowo wójt, burmistrz lub prezydent miasta wydaje decyzję o zakazie wykonywania przez przedsiębiorcę działalności objętej wpisem w przypadku, gdy ${ }^{48}$.

a) przedsiębiorca złożył oświadczenie, o którym mowa w art. 9c ust. 4, niezgodne ze stanem faktycznym;

b) przedsiębiorca nie usunął naruszeń warunków wymaganych prawem do wykonywania działalności regulowanej w wyznaczonym przez organ terminie;

45 Szerzej na ten temat M. Etel, Undertaking, conducting and terminating economic activity in Poland, Białystok 2014, s. 200.

46 Art. 368 ust. 1 p.o.ś.

47 Art. 22 a ust. 1 u.p.t.

48 Art. 9j ust. 1 ustawy z dnia 13 września 1996 roku o utrzymaniu czystości i porządku w gminach (Dz.U. z 2017 r. poz. 1289 ze zm.); dalej: u.u.p.c.g. Decyzja podlega natychmiastowemu wykonaniu. W przypadku wydania decyzji wójt, burmistrz lub prezydent miasta $\mathrm{z}$ urzędu wykreśla przedsiębiorcę z rejestru. 
c) stwierdzi rażące naruszenie warunków wymaganych prawem do wykonywania działalności regulowanej przez przedsiębiorcę.

\section{Wnioski}

W ramach samorządowych organów ochrony środowiska, na podstawie p.o.ś., można wskazać wójta, burmistrza lub prezydenta miasta, starostę, sejmik województwa, marszałka województwa czy też wojewodę. Niewątpliwie są to organy mające kompetencje również w zakresie administracji gospodarczej.

Co więcej, dostrzegalny jest wpływ samorządowych organów ochrony środowiska na działalność gospodarczą na każdym jej etapie — zarówno podejmowania, wykonywania, jak i zakończenia działalności gospodarczej. Samorządowe ograny ochrony środowiska pojawiają się również w przypadku kontroli nad działalnością gospodarczą oraz reglamentacji działalności gospodarczej, a także mają możliwość wydawania decyzji o wstrzymaniu działalności gospodarczej. Powyższe pozwala dostrzec, że samorządowe organy ochrony środowiska mają wiele uprawnień w zakresie ochrony środowiska, zwłaszcza w kontekście aktywności przedsiębiorców.

Tego typu rozwiązanie można ocenić pozytywnie - samorządowe organy ochrony środowiska mają największą wiedzę na temat problemów występujących na obszarze ich działania, a do tego mają możliwość stosunkowo szybkiej reakcji. Warto jednak pamiętać, że ochrona środowiska, w przypadku analizowanych organów, nie jest ich podstawowym i jedynym zadaniem. Ma ona wymiar raczej dodatkowych, a przy tym czaso- i kosztochłonnych uprawnień, do tego wymagających specjalistycznej wiedzy. Biorąc pod uwagę wielość zadań i wyzwań, przed którymi często stają obecnie organy JST, realizując inne kompetencje niezwiązane z ochroną środowiska, można podstawić pytanie, czy samorządowe organy środowiska mają szansę właściwej i skutecznej realizacji zadań z zakresu ochrony środowiska. Jak dalece też organy te są przygotowane, by takie zadania związane z ochroną środowiska wykonywać? Niewątpliwie jednoznaczna odpowiedź na nie wymaga jednak dalszych badań.

\section{Bibliografia}

Barczak A., Kowalewska E., Zadania samorząu terytorialnego w ochronie środowiska. Aspekty materialne i finansowe, Warszawa 2015.

Bukowski Z., Możliwości prawne wprowadzenia zakazu spalania określonych paliw stałych na terenie gminy, „Studia z Zakresu Prawa, Administracji i Zarządzania” 1, 2012.

Ciechanowicz-McLean J., Bukowski Z., Rakoczy B., Prawo ochrony środowiska. Komentarz, Warszawa 2008. 
Ciechanowicz-McLean J., Prawo i polityka ochrony środowiska, Warszawa 2009.

Czech E.K., Kompetencje samorządu terytorialnego w zakresie ochrony środowiska a możliwość prywatyzacji przedsięwzięć publicznych, [w:] Integracja Polski z Uniq Europejska w dziedzinie ochrony środowiska - problemy, korzyści, zagrożenia, red. M. Burchard-Dziubińska, Łódź 2000.

Czech E.K., Kropiewnicka M., Międzynarodowa wspótpraca polskiego samorządu terytorialnego szczebla powiatowego w zakresie ochrony środowiska realizowanej w zgodzie ze zrównoważonym rozwojem, „Białostockie Studia Prawnicze” 2012.

Etel M., [w:] Prawo pocztowe. Komentarz, red. M. Chołodecki, A. Piszcz, T. Skoczny, Warszawa 2018.

Etel M., Regulowana działalność gospodarcza a zasada wolności gospodarczej, „Państwo i Prawo” $2007, \mathrm{nr} 2$.

Etel M., Undertaking, conducting and terminating economic activity in Poland, Białystok 2014.

Górski M., Ochrona środowiska jako zadanie administracji publicznej, Łódź 1992.

Kohutek K., Zasady podejmowania działalności regulowanej, PPH 2005, nr 6.

Korzeniowski P., Prawa i obowiązki przedsiębiorców w ochronie środowiska. Zarys encyklopedyczny, Warszawa 2010.

Kosieradzka-Federczyk A., Funkcje administracyjne w gospodarce odpadami na przyktadzie gminy, [w:] Prawne aspekty gospodarowania zasobami środowiska. Korzystanie z zasobów środowiska, red. B. Rakoczy, M. Szalewska, K. Karpus, Torun 2014.

Kosikowski C., Ustawa o swobodzie działalności gospodarczej. Komentarz, Warszawa 2012.

Kosikowski C., Zezwolenia na działalność gospodarcza w prawie polskim, Warszawa 1997.

Kosikowski C., Zezwolenie na działalność gospodarcza, [w:] Administracyjne prawo gospodarcze, red. L. Kieres, Wrocław 2009.

Kosikowski C., Etel M., Nowe prawo działalności gospodarczej, Białystok 2014.

Piszcz A., Zawieszenie i wznowienie wykonywania działalności gospodarczej, PUG 2009, nr 10.

Powałowski A., Ocena regulacji prawnej zawieszenia wykonywania działalności gospodarczej, GSP 2010, nr 2.

Romas K., Opłaty środowiskowe, gdy działalność została zawieszona, „Gazeta Podatkowa” 10.01.2013, http://www.gofin.pl/17,2,306,113384,oplaty-srodowiskowe-gdy-dzialalnosc-zostala-zawieszona. html (dostęp: 18.09.2019).

Roszewska K., Wplyw zawieszenia działalności gospodarczej na ubezpieczenia emerytalne i rentowe, „Z Zagadnień Zabezpieczenia Społecznego” 2011, nr 3.

Strzyczkowski K., Prawo gospodarcze publiczne, Warszawa 2013.

Suski T., Kierzkowska J., Rola organów samorzadu terytorialnego w zakresie prawnej ochrony przyrody w Polsce, [w:] Prawne aspekty gospodarowania zasobami środowiska. Korzystanie z zasobów środowiska, red. B. Rakoczy, M. Szalewska, K. Karpus, Toruń 2014.

Szydło M., Reglamentacja podejmowania działalności gospodarczej w nowej ustawie o swobodzie działalności gospodarczej, PUG 2004, nr 12.

Walas M., Organy ochrony środowiska w Polsce, PPOŚ 2009, nr 1.

Waligórski M.A., Prawo przedsiębiorcy do zawieszania $i$ wznawiania wykonywania działalności gospodarczej, PUG 2009, $\mathrm{nr} 8$. 


\title{
The participation of municipal environmental protection authorities in the economic activities of the entrepreneur
}

\begin{abstract}
Summary
The purpose of the article is to analyse the participation of municipal environmental protection authorities in restriction of economic freedom to protect the environment in Poland. Therefore, the author examined the participation of authorities at every stage of economic activity. The paper also shows the normative solutions in this area. Study of the outlined problems was mainly based on the dogmatic and legal method. The article finishes with synthetic conclusions.
\end{abstract}

Keywords: environmental protection, business activity, entrepreneur, environmental protection authority. 